NOTE

\title{
Effects of high salinity, high temperature and pH on capsid structure of white spot syndrome virus
}

\author{
Weiyu Chen ${ }^{1,2, *}$, Heng Zhang ${ }^{2, *}$, Li Gu${ }^{2}$, Fang Li $^{2}$, Feng Yang ${ }^{2, * *}$ \\ ${ }^{1}$ College of Oceanography and Environmental Science of Xiamen University, Xiamen 361005, PR China \\ ${ }^{2}$ Key Laboratory of Marine Biogenetic Resources, Third Institute of Oceanography, Xiamen 361005, PR China
}

\begin{abstract}
The structural stability of white spot syndrome virus (WSSV) capsids at high salinity, high temperature and various $\mathrm{pH}$ values was studied. To obtain the viral capsids, the nucleocapsids were treated with high salinity. The results showed that high salinity treatment can cause the dissociation of VP15 and most of VP95 from the nucleocapsid, but there were no noticeable alterations in morphology and ultrastructure of the nucleocapsid and capsid. The capsids retained morphological integrity at temperatures $<45^{\circ} \mathrm{C}$ but became aberrant at $>60^{\circ} \mathrm{C}$. In addition, the capsids were relatively resistant to strong acid conditions and were tolerant to a broad $\mathrm{pH}$ range of 1 to 10 . However, morphological change occurred at $\mathrm{pH}$ 10.5. The capsids broke up into small pieces at $\mathrm{pH} 11$ and completely degraded in 0.1 and $1.0 \mathrm{M} \mathrm{NaOH}$. These results indicated that the WSSV capsid is acid-stable and alkali-labile.
\end{abstract}

KEY WORDS: WSSV $\cdot$ Capsid $\cdot$ Transmission electron microscopy $\cdot$ Structural stability

\section{INTRODUCTION}

White spot syndrome virus (WSSV), the only member of the family Nimaviridae, is a rod-shaped enveloped virus with a double-stranded circular DNA genome encoding approximately 180 proteins (van Hulten et al. 2001, Yang et al. 2001, Chen et al. 2002). The virion has a multilayered structure comprising a nucleocapsid surrounded by a thick, lipidcontaining envelope (Zhou et al. 2008). About 40 structural proteins of the WSSV virion have been so far identified by mass spectrometry analysis, including 8 nucleocapsid proteins: VP664, VP190, VP136, VP95, VP76, VP60, VP51 and VP15 (Tsai et al. 2004, Wu \& Yang 2006, Xie et al. 2006, Li et al. 2007). Among them, VP664 is the major capsid protein regularly distributed around the periphery of the nucleocapsid and it may contribute primarily to the assembly and morphogenesis of the virion (Leu et al. 2005). VP51 (also named VP466 or VP51C) is responsible for envelopment of the nucleocapsid by direct interaction with envelope protein VP26 (Wan et al. 2008).
VP15 is a DNA-binding protein functionally similar to histone (Zhang et al. 2001, Witteveldt et al. 2005) and considered to be a core protein (Tsai et al. 2006). Reportedly, high salinity treatments could not dissociate WSSV capsid but could lead to the complete removal of VP15 and genome from the viral nucleocapsid (Tsai et al. 2006, Wu \& Yang 2006). VP15 was found to contribute to the viral DNA packaging process by directly condensing viral DNA (Liu et al. 2010, Sangsuriya et al. 2011).

The nucleocapsid is formed by assembling capsid proteins and viral genomic DNA or RNA. In addition to the protection of viral genomes, the capsid also participates in the delivering of viral genome during the infection process and encapsidation of viral genome during the packaging of nascent progeny virus (Bartenschlager et al. 1990, Hirsch et al. 1990). Although significant progress has been made to identify the WSSV major capsid proteins, little work has been done to analyze the properties of the viral capsid itself. In the present study, we explored the stability of the WSSV capsid at high salinity, high 
temperature and various $\mathrm{pH}$ values, which will facilitate our understanding of the assembly mechanism of the WSSV nucleocapsid or capsid and help to develop appropriate control strategies.

\section{MATERIALS AND METHODS}

\section{Purification of WSSV capsids}

The WSSV virions and nucleocapsids were prepared and purified as previously described (Xie et al. 2005, 2006). To obtain capsids, the nucleocapsids that had been suspended in TNM buffer $(20 \mathrm{mM}$ Tris$\mathrm{HCl} / \mathrm{pH} 7.6,150 \mathrm{mM} \mathrm{NaCl}, 2 \mathrm{mM} \mathrm{MgCl}_{2}$ ) were mixed with an equal volume of TNK high salinity buffer $(20 \mathrm{mM}$ Tris- $\mathrm{HCl} / \mathrm{pH}$ 7.6, 0.8 M NaCl, 0.8 M $\mathrm{KCl}$ ). The solution became quite viscous due to release of viral genomic DNA from the nucleocapsids. Then, an equal volume of distilled water was added and mixed by inversion. The resulting fibrous precipitate was washed twice with TNM buffer and

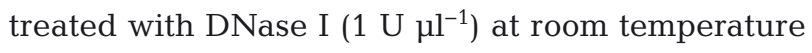
for $2 \mathrm{~h}$ to remove the DNA. The capsids were sedimented by centrifugation at $2000 \times g$ for $20 \mathrm{~min}$ at $4^{\circ} \mathrm{C}$ and resuspended in TNM buffer for further analysis. The viral genomic DNA in purified capsids was extracted with phenol/chloroform and detected by agarose gel electrophoresis.

\section{Temperature and $\mathrm{pH}$ treatments}

The capsids suspended in TNM buffer were incubated for $1 \mathrm{~h}$ at $37,45,60,80$ or $100^{\circ} \mathrm{C}$. Then the capsid suspensions were immediately cooled on ice and examined by transmission electron microscopy (TEM). Furthermore, to investigate the tolerance of WSSV capsid to extreme $\mathrm{pH}$, the capsids were incubated in 0.1 or $1 \mathrm{M} \mathrm{HCl}$, as well as 0.1 or $1 \mathrm{M} \mathrm{NaOH}$ at room temperature for $1 \mathrm{~h}$ and then dialyzed overnight against TMS buffer at $4^{\circ} \mathrm{C}$ for TEM and sodium dodecyl sulphate polyacrylamide gel electrophoresis (SDS-PAGE) analyses, respectively. In order
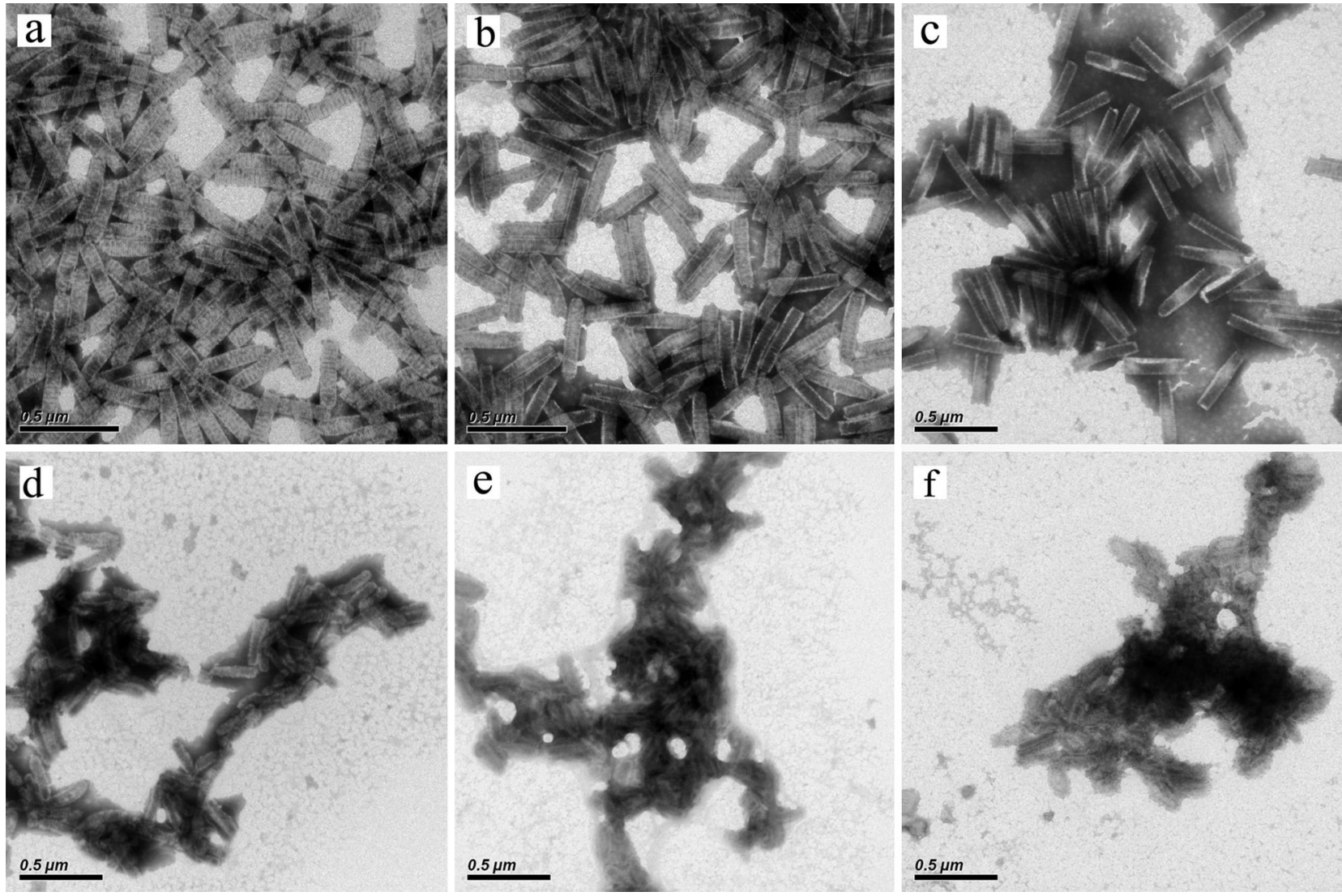

Fig. 1. Electron micrographs of (a) purified white spot syndrome virus (WSSV) nucleocapsids, (b) empty purified capsids, and heat-treated capsids at (c) 37 , (d) 60 , (e) 80 and (f) $100^{\circ} \mathrm{C}$ 
to study the stability of WSSV capsid under alkaline conditions, the capsids were incubated in $0.1 \mathrm{M}$ carbonate-bicarbonate buffer at $\mathrm{pH}$ 9, 9.5, 10, 10.5 or 11 at room temperature for $1 \mathrm{~h}$ with slight shaking. Finally, the samples were examined by TEM.

\section{Transmission electron microscopy (TEM)}

Viral specimens were adsorbed onto 200 mesh carbon-coated nickel grids for $30 \mathrm{~min}$ at room temperature, and the excess liquid was carefully blotted with Whatman filter paper. Then, the grids were washed 3 times with distilled water and negatively stained with $2 \%$ phosphotungstic acid (PTA) for $1 \mathrm{~min}$. The excess stain was drained off with filter paper and the specimens were examined with a TEM (JEM-1230, JEOL).

\section{Sodium dodecyl sulfate-polyacrylamide gel electrophoresis (SDS-PAGE)}

The nucleocapsids, capsids or treated samples were mixed with equal volumes of $2 \times$ Laemmli buffer (Laemmli 1970) with 10\% $\beta$-ME, heated at $100^{\circ} \mathrm{C}$ for $10 \mathrm{~min}$ and separated by $12 \%$ polyacrylamide gel. Protein bands were visualized using Coomassie brilliant blue R-250 staining.

\section{RESULTS}

The WSSV capsids were prepared by high salinity treatment. The viral genomic DNA was not detected from purified capsids by agarose gel electrophoresis (data not shown). The TEM results revealed that there was no significant difference in the morphological appearance between the nucleocapsids (Fig. 1a) and capsids (Fig. 1b), and the profiles of the capsid subunits (capsomers) were clearly visible on their surface, suggesting that ionic interactions between capsomers may make a relatively small contribution to the stability of the capsid. Whether perceptible differences in the protein composition between the nucleocapsids and capsids occurred was not clear. In order to visualize the protein components, the nucleocapsids and capsids were analyzed by SDS-PAGE. The results indicated that the high salinity treatment completely removed the core protein VP15 from the nucleocapsids (Fig. 2, Lanes 1 and 2), indicating that VP15 is not a structural component of the viral capsids. In addition, the VP95 protein was significantly

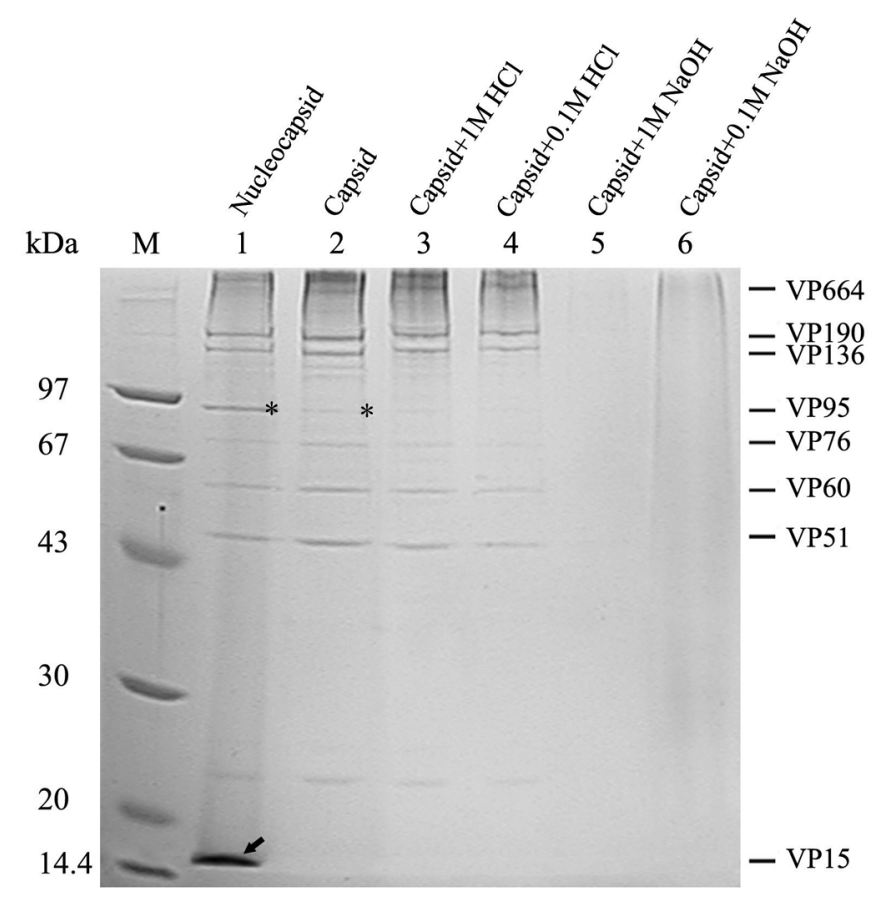

Fig. 2. Sodium dodecyl sulphate polyacrylamide gel electrophoresis (SDS-PAGE) analysis of purified white spot syndrome virus (WSSV) nucleocapsid (Lane 1), empty capsids (Lane 2), $1 \mathrm{M} \mathrm{HCl}$-treated capsids (Lane 3), $0.1 \mathrm{M}$-treated capsids (Lane 4), $1 \mathrm{M} \mathrm{NaOH}$-treated capsids (Lane 5) and $0.1 \mathrm{M} \mathrm{NaOH}$-treated capsids (Lane 6) for structural proteins, including VP95 (asterisks) and core protein VP15 (arrow). Lane M: low molecular mass protein marker

reduced in the capsids compared with the nucleocapsids (Fig. 2, Lanes 1 and 2). The results of the high salinity treatment suggested that the partial dissociation of VP95 from the nucleocapsids may be related to the release of VP15 and viral DNA.

To estimate the effects of different temperature on capsid structure, the capsids suspended in TNM buffer were incubated for $1 \mathrm{~h}$ at $37,45,60,80$ or $100^{\circ} \mathrm{C}$. The TEM observation showed that no obvious conformation changes were observed in the capsids treated at $37^{\circ} \mathrm{C}$ (Fig. 1C) or $45^{\circ} \mathrm{C}$ (data not shown). However, the surface structure of the capsid was no longer visible after incubating at $60^{\circ} \mathrm{C}$ for $1 \mathrm{~h}$ (Fig. 1d). Heating up to 80 or $100^{\circ} \mathrm{C}$, the capsids were further disrupted into amorphous masses (Fig. 1e,f). The results indicated that the structure of the capsids is stable at a temperature lower than $45^{\circ} \mathrm{C}$, but as the temperature rises, the capsids form disorganized aggregates due to thermal denaturation.

Moreover, to investigate the tolerance of WSSV capsid to extreme $\mathrm{pH}$, the capsids were incubated in 0.1 or $1 \mathrm{M} \mathrm{HCl}$, as well as 0.1 or $1 \mathrm{M} \mathrm{NaOH}$. The TEM results showed that the $0.1 \mathrm{M} \mathrm{HCl}$ treatment did not 

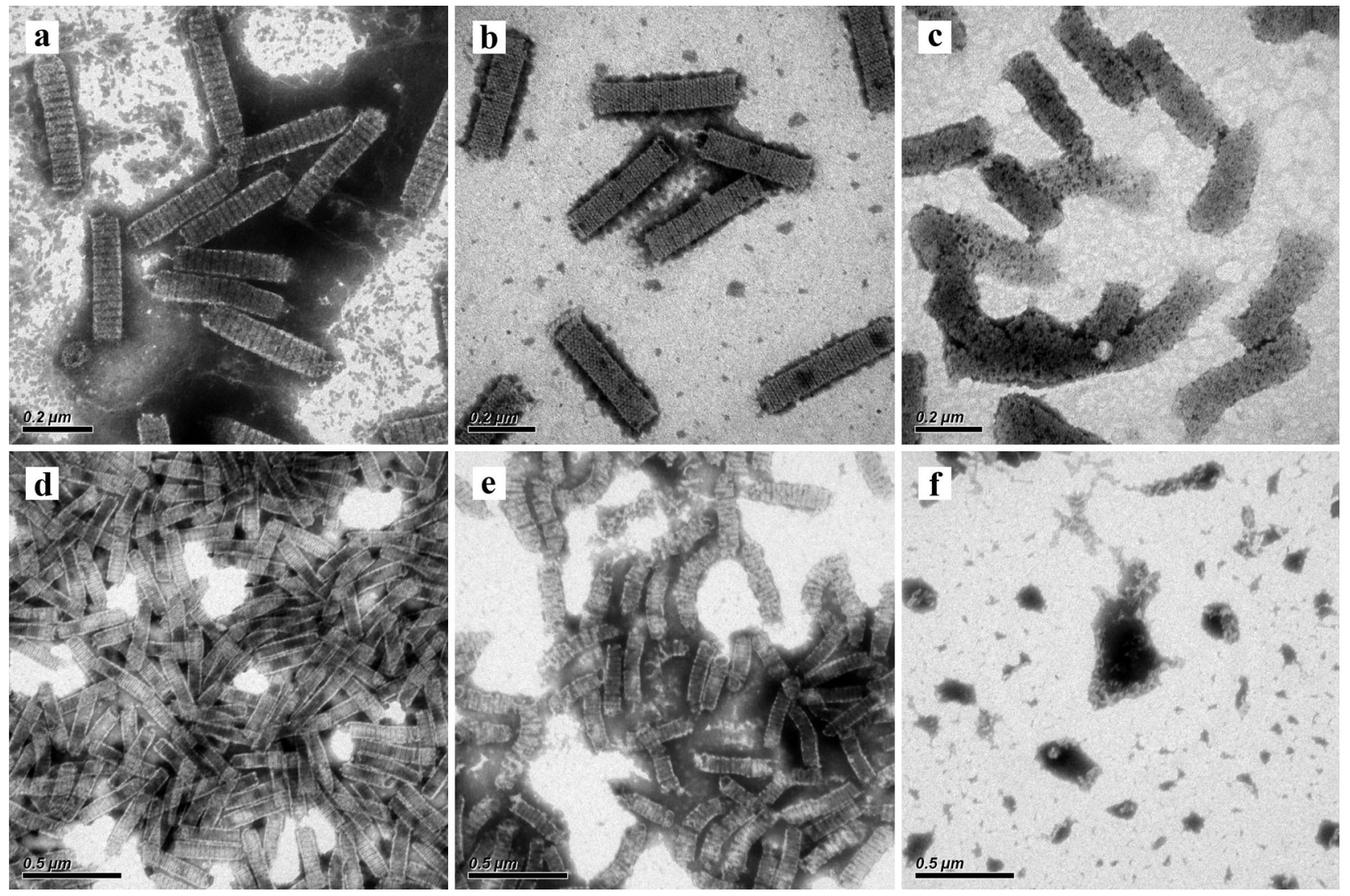

Fig. 3. Electron microscopic analysis of (a) white spot syndrome virus (WSSV) capsids, (b) 0.1 M HCl-treated capsids, (c) 1 M HCl-treated capsids, and capsids incubated at (d) pH 10, (e) pH 10.5 and (f) $\mathrm{pH} 11$

cause significant change in capsid morphology, and capsomeres remained clearly discernible (Fig. 3a,b). However, the capsid was disrupted into amorphous structure that no longer retained the capsomeric detail, but its outline was still visible after treatment with $1 \mathrm{M} \mathrm{HCl}$ (Fig. 3c). The acid-treated protein components were further analyzed by SDS-PAGE. As shown in Fig. 2, there was no obvious change in the protein bands between $\mathrm{HCl}$-treated and untreated capsids (Fig. 2, Lanes 2, 3 and 4). On the contrary, after 0.1 or $1 \mathrm{M} \mathrm{NaOH}$ treatment, no capsids or small pieces were visible by TEM (data not shown), and also no distinguishable protein bands were seen by SDS-PAGE (Fig. 2, Lanes 5 and 6), suggesting that viral capsid proteins are likely to undergo degradation under strong alkaline conditions.

To further examine the stability of WSSV capsid under alkaline conditions, the capsids were incubated in $0.1 \mathrm{M}$ carbonate-bicarbonate buffer at $\mathrm{pH} 9$, 9.5, 10, 10.5 or 11 . The TEM results showed that viral capsids appeared to have no significant morphologi-

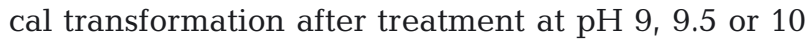

(Fig. 3d). However, at pH 10.5, the capsids appeared to undergo breakage and their structure became loose (Fig. 3e). Surprisingly, the capsids were completely disrupted into small patches at pH 11 (Fig. 3f). Although, alkaline conditions of $\mathrm{pH} 10.5$ or greater led to significant disruption of the capsid structure, we did not observe any free capsomeres.

\section{DISCUSSION}

In order to gain insight into the structure, organization and assembly of the WSSV nucleocapsid and capsid, we examined their stability to high salinity, high temperature and extreme $\mathrm{pH}$. After the high salinity treatment, removal of the core protein VP15 and viral genomic DNA appeared to have no effect on the morphology and ultrastructure of nucleocapsid or capsid (Fig. 1a,b), suggesting that both VP15 and DNA are not required for the maintenance of the capsid structure. The data from SDS-PAGE showed that, concomitant with the release of VP15, most of 
the VP95 was also released from nucleocapsids (Fig. 2, Lanes 1 and 2). VP95 is a protein present in both the viral envelope and nucleocapsid fractions (Xie et al. 2006), but its functional properties have not yet been examined. Based on the above experimental results, we speculated that VP95 might participate in the release of virus nucleoprotein core consisting of VP15 and genomic DNA.

The $\mathrm{pH}$ dependence on the stability of the capsids was assessed by incubating them at various $\mathrm{pH}$ values. The capsids were found to be acid resistant but complete disruption took place under strong alkaline conditions ( 0.1 or $1 \mathrm{M} \mathrm{NaOH}$ ). In addition, the capsids' structure became broken and loose at $\mathrm{pH} 10.5$ (Fig. 3e) and disrupted into small patches at $\mathrm{pH} 11$ (Fig. 3f). Normally, for large DNA viruses, uncoating (loss of viral capsid) is required prior to viral genome delivery into the nucleus. The above experimental data provided a suggestion that the uncoating of WSSV may occur in a relatively alkaline compartment within the host cell. The mechanism of entry and uncoating of WSSV is unknown at present, and further studies are needed to verify our hypothesis.

In conclusion, in the present study, we found that (1) the high salinity treatment can cause the dissociation of VP15 and most of VP95 from the nucleocapsid, but with no noticeable alterations in morphology and ultrastructure of the nucleocapsid and capsid, which suggests that these peptides are not part of its structure; (2) at temperatures lower than $45^{\circ} \mathrm{C}$ the capsids retained their morphological integrity but became aberrant at temperatures higher than $60^{\circ} \mathrm{C}$; and (3) capsids are acid resistant but not alkaline resistant, as shown by stability at a broad $\mathrm{pH}$ range (1 to 10) but degradation at $\mathrm{pH} 10.5$.

Acknowledgements. This investigation was supported by National Basic Research Program of China (973 Program) (No.2012CB114401), Natural Science Foundation of China (No. 31072243) and China Agriculture Research System-47.

\section{LITERATURE CITED}

Bartenschlager R, Junker-Niepmann M, Schaller H (1990) The $\mathrm{P}$ gene product of hepatitis $\mathrm{B}$ virus is required as a structural component for genomic RNA encapsidation. J Virol 64:5324-5332

Chen LL, Leu JH, Huang CJ, Chou CM, Chen SM, Wang CH, Lo CF, Kou GH (2002) Identification of a nucleocapsid protein (VP35) gene of shrimp white spot syndrome virus and characterization of the motif important for targeting VP35 to the nuclei of transfected insect cells. Virology 293:44-53
Hirsch RC, Lavine JE, Chang LJ, Varmus HE, Ganem D (1990) Polymerase gene products of hepatitis B viruses are required for genomic RNA packaging as well as for reverse transcription. Nature 344:552-555

> Laemmli UK (1970) Cleavage of structural proteins during the assembly of the head of bacteriophage T4. Nature 227:680-685

Leu JH, Tsai JM, Wang HC, Wang AHJ, Wang $\mathrm{CH}_{\text {, Kou }}$ GH, Lo CF (2005) The unique stacked rings in the nucleocapsid of the white spot syndrome virus virion are formed by the major structural protein VP664, the largest viral structural protein ever found. J Virol 79: 140-149

Li Z, Lin Q, Chen J, Wu JL, Lim TK, Loh SS, Tang X, Hew CL (2007) Shotgun identification of the structural proteome of shrimp white spot syndrome virus and iTRAQ differentiation of envelope and nucleocapsid subproteomes. Mol Cell Proteomics 6:1609-1620

Liu Y, Wu J, Chen H, Hew CL, Yan J (2010) DNA condensates organized by the capsid protein VP15 in white spot syndrome virus. Virology 408:197-203

Sangsuriya $\mathrm{P}$, Senapin S, Huang WP, Lo CF, Flegel TW (2011) Co-interactive DNA-binding between a novel, immunophilin-like shrimp protein and VP15 nucleocapsid protein of white spot syndrome virus. PLoS ONE 6: e25420

Tsai JM, Wang HC, Leu JH, Hsiao HH, Wang AHJ, Kou GH, Lo CF (2004) Genomic and proteomic analysis of thirtynine structural proteins of shrimp white spot syndrome virus. J Virol 78:11360-11370

Tsai JM, Wang HC, Leu JH, Wang AH, Zhuang Y, Walker PJ, Kou GH, Lo CF (2006) Identification of the nucleocapsid, tegument, and envelope proteins of the shrimp white spot syndrome virus virion. J Virol 80:3021-3029

van Hulten MCW, Witteveldt J, Peters S, Kloosterboer N and others (2001) The white spot syndrome virus DNA genome sequence. Virology 286:7-22

> Wan Q, Xu L, Yang F (2008) VP26 of white spot syndrome virus functions as a linker protein between the envelope and nucleocapsid of virions by binding with VP51. J Virol 82:12598-12601

Witteveldt J, Vermeesch AMG, Langenhof M, de Lang A, Vlak JM, van Hulten MCW (2005) Nucleocapsid protein VP15 is the basic DNA binding protein of white spot syndrome virus of shrimp. Arch Virol 150:1121-1133

Wu C, Yang F (2006) Localization studies of two white spot syndrome virus structural proteins VP51 and VP76. Virol J 3:76

Xie X, Li H, Xu L, Yang F (2005) A simple and efficient method for purification of intact white spot syndrome virus (WSSV) viral particles. Virus Res 108:63-67

> Xie X, Xu L, Yang F (2006) Proteomic analysis of the major envelope and nucleocapsid proteins of white spot syndrome virus. J Virol 80:10615-10623

> Yang F, He J, Lin X, Li Q, Pan D, Zhang X, Xu X (2001) Complete genome sequence of the shrimp white spot bacilliform virus. J Virol 75:11811-11820

Zhang X, Xu X, Hew CL (2001) The structure and function of a gene encoding a basic peptide from prawn white spot syndrome virus. Virus Res 79:137-144

> Zhou Q, Li H, Qi YP, Yang F (2008) Lipid of white-spot syndrome virus originating from host-cell nuclei. J Gen Virol 89:2909-2914

Submitted: May 21, 2012; Accepted: July 27, 2012

Proofs received from author(s): October 10, 2012 